\title{
The relationship between cation-anion differences in dairy cow diets and some blood indices levels and milk composition ${ }^{1}$
}

\author{
S. Krzywiecki, R. Bodarski ${ }^{1}$, J. Preś and W. Luczak \\ Agricultural University of Wrockaw, \\ Department of Animal Nutrition and Feed Quality \\ Chelmońskiego 38C, 51-630 Wrocław, Poland
}

\begin{abstract}
In dairy cows, changes in dietary cation-anion differences (DCAD) induced significant differences in milk composition and in the blood $\mathrm{Ca}, \mathrm{P}_{\text {inorg. }}$ and $\mathrm{Mg}$ content, as well as in some acid-base balance parameters. DCAD exceeding $+350 \mathrm{meq} / \mathrm{kg}$ DM decreased the DM and protein content in milk. The same was found for lactose when DCAD were $+330 \mathrm{meq} / \mathrm{kg}$ DM. The highest serum Ca level was observed when $\mathrm{DCAD}$ were about $+350 \mathrm{meq} / \mathrm{kg} \mathrm{DM}$. Increases in DCAD decreased $\mathrm{Mg}$ and $\mathrm{P}_{\text {inorg. }}$ concentrations in serum and blood $\mathrm{pCO}_{2}$ and $\mathrm{BB}$, however, the milk fat content and blood $\mathrm{pH}$ increased.
\end{abstract}

KEY WORDS: dairy cows, DCAD, milk composition, physiological status

\section{INTRODUCTION}

Tucker et al. (1991) and West et al. (1991) were the first to evaluate dietary cationanion differences (DCAD) for cows in lactation. Recently, the influence of a wide range of DCAD on dry matter intake, milk yield and composition (Delaquis and Block, 1995; Roche et al., 2003), acid-base status, blood and urinary mineral levels (ApperBossard and Peyrand, 2004) was evaluated. West et al. (1991) reported that milk yield increased when DCAD were $+32 \mathrm{meq} / 100 \mathrm{~g}$ DM. Later, West et al. (1992) showed linear growth of dry matter intake when DCAD increased to $+46 \mathrm{meq} / 100 \mathrm{~g}$ DM. In our study the influence of DCAD in dairy cow diets with different levels of hay and silages on milk composition and physiological status of animals was examined.

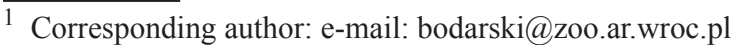




\section{MATERIAL AND METHODS}

Two experiments with Black-and-White cows in mid-lactation were conducted over a period of 3 months. The average milk yield per lactation was 50001 . Five protein- and energy-balanced rations with different ratio of hay and silages were tested (Table 1). There were 12 cows per group. The feed mineral composition was determined (AOAC, 1995). DCAD was calculated using the formula of Tucker et al. (1991) (meqK+meqNa)(meqCl+meqS). Milk composition was determined on Milkoscan equipment, the levels of $\mathrm{Ca}, \mathrm{P}_{\text {inorganic }}$ and $\mathrm{Mg}$ in blood serum were determined photometricaly with the use of kits (POCH, Gliwice). Some indicators of blood acid-base balance ( $\left.\mathrm{pH}, \mathrm{pCO}_{2}, \mathrm{BB}\right)$ were assayed by the Astrup method on Corning equipment.

\section{RESULTS}

DCADs in diets with wilted alfalfa-grass silage were significantly higher in comparison with diets containing hay or wilted Italian ryegrass silage (Table 1).

Table 1. Composition and DCAD (meq/kg DM) of experimental diets

\begin{tabular}{llc}
\hline Diet & Amount of feeds, kg per day per head & DCAD \\
\hline I & Maize silage 25; meadow hay 6; rapeseed meal 1; mineral mixture 0.1 & 422 \\
II & Maize silage 25; meadow hay 3; wilted grass-lucerne silage 8; & 449 \\
III & Rapeseed meal 0.5; mineral mixture 0.1 & 469 \\
IV & Maize silage 25; wilted grass-lucerne silage 16; mineral mixture 0.1 & 244 \\
V & Maize silage 25; meadow hay 6; rapeseed meal 1; mineral mixture 0.1 & 271 \\
\hline
\end{tabular}

When DCAD exceed $+350 \mathrm{meq} / \mathrm{kg}$ DM (Figure 1), milk DM and protein contents declined. The lactose content decreased when DCAD equaled $+330 \mathrm{meq} /$ $\mathrm{kg}$ DM. In contrast, the opposite relationship for milk fat was found. The fat level rose nearly linearly with increasing DCAD. The Ca concentration was highest when DCAD equaled $+350 \mathrm{meq} / \mathrm{kg} \mathrm{DM}$, however, plasma $\mathrm{Mg}$ and especially $\mathrm{P}_{\text {inorganic }}$ levels dramatically decreased when DCAD increased. The predominance of dietary cations over anions raised blood $\mathrm{pH}$, while as DCAD increased, carbon dioxide partial pressure and buffer base decreased.

\section{DISCUSSION}

Many authors (Tucker et al., 1991; Delaquis and Block, 1995; Apper-Bossard and Peyeraud, 2004) demonstrated significant differences in the effects of anion supplementation on decreasing DM intake. This could be explained by the fact that in the study by Apper-Bossard and Peyrand (2004), the diet did not 

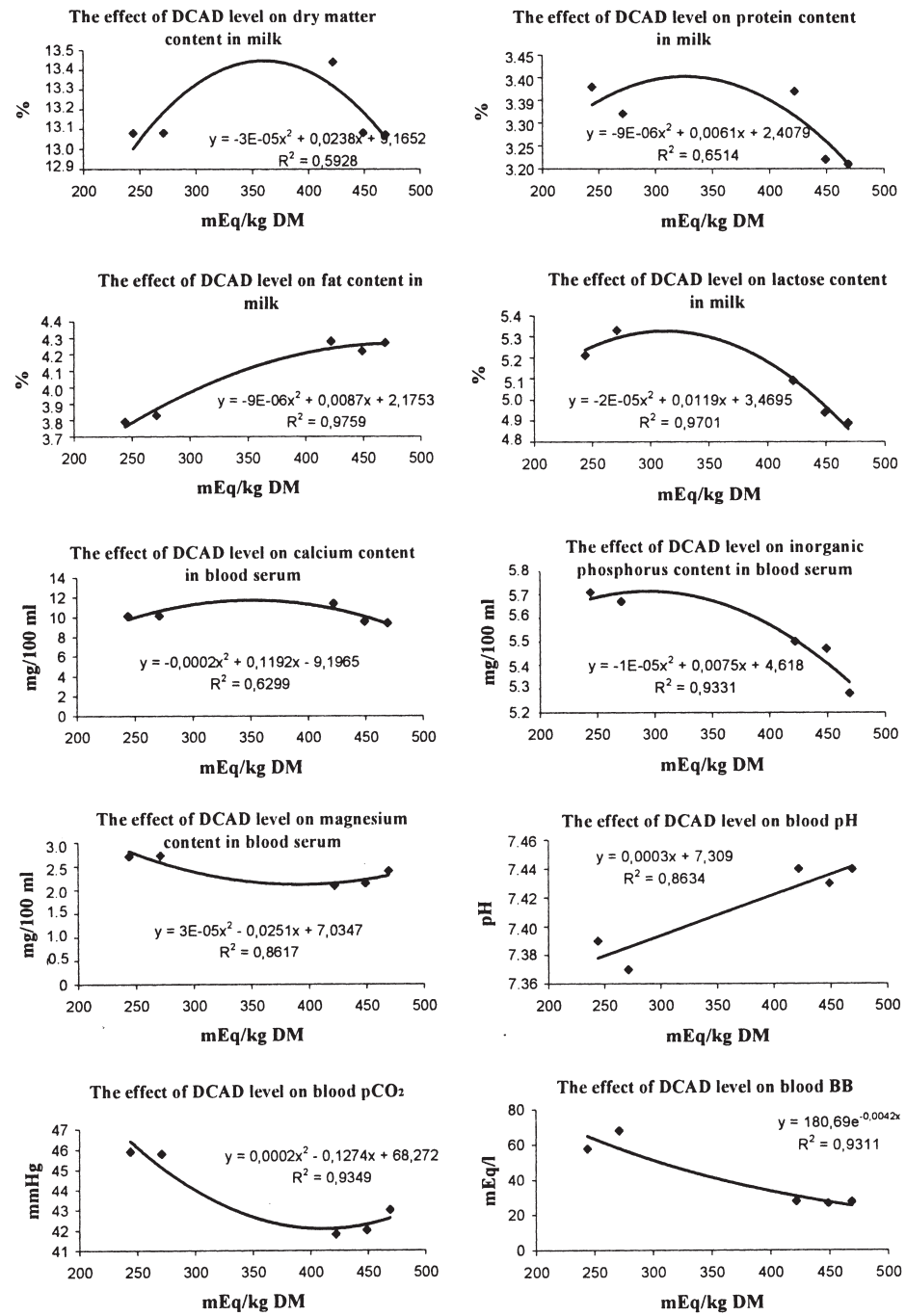

Figure 1. Influence of DCAD on milk composition and blood serum levels of some minerals, as well as on some physiological parameters in blood

contain a buffer agent $\left(\mathrm{NaHCO}_{3}\right)$. Also in that study, cows fed diets with lower DCAD demonstrated lower milk yield, as well as a significant decrease in blood $\mathrm{pH}$ and blood buffer base. It could be stated that differences in DCAD levels between +100 and $+400 \mathrm{meq} / \mathrm{kg}$ DM do not cause significant changes in feed intake and milk production when a dietary buffer is used. Elimination of $\mathrm{NaHCO}_{3}$ from the diet induced an increase of feed intake and milk yield when the DCAD level rose to about $+300 \mathrm{meq} / \mathrm{kg} \mathrm{DM}$. The increased milk fat level could be related to the 
difference in the $\mathrm{C}_{2} / \mathrm{C}_{3}$ ratio in the rumen caused by a higher DCAD level (ApperBossard and Peyeraud, 2004) or with the S supplement (Tucker et al., 1991).

An increased blood $\mathrm{pH}$ level and simultaneous increase in the excess of cations over anions to over $+200 \mathrm{meq} / \mathrm{kg}$ DM, similarly as in our study, was reported by Roche at al. (2003). They found that DCAD levels over $+200 \mathrm{meq} / \mathrm{kg}$ DM induced a slight drop in milk yield and concentration of protein, fat and lactose in milk. This excess led to higher $\mathrm{Na}$ and lower $\mathrm{Cl}$ and $\mathrm{S}$ excretion in urine, as well as slight decrease in feed intake and body weight gain.

\section{CONCLUSIONS}

In lactating dairy cows, changes in dietary cation-anion differences caused significant differences in milk composition, the concentrations of $\mathrm{Ca}, \mathrm{P}_{\text {inorganic }}$ and $\mathrm{Mg}$ in blood serum, as well as in the level of some acid-base balance indicators.

\section{REFERENCES}

AOAC, 1995. Association of Official Analytical Chemists, Official Methods of Analysis. 16 ${ }^{\text {th }}$. Edition. Arlington, VA

Apper-Bossard E., Peyeraud J.L., 2004. Dietary cation-anion difference could enhance acid-base status of lactating dairy cows submit to subacidosis. J. Anim. Feed Sci. 1, 27-30

Delaquis A.M., Block E., 1995. Dietary cation-anion difference, acid-base status, mineral metabolism, renal function, and milk production of lactating cows. J. Dairy Sci. 78, 2259-2284

Roche J.R., Dalley D., Moate P., Grainger C., Rath M., O’Mara F., 2003. Dietary cation-anion difference and the health and production of pasture-fed dairy cows. 1. Dairy cows in early lactation. J. Dairy Sci. 86, 970-978

Tucker W.B., Hogue J.F., Waterman D.F., Swenson T.S., Xin Z., Hemken R.W., Jackson J.A., Adams G.D., Spicer L.J., 1991. Role of sulfur and chloride in the dietary cation-anion balance equation for lactating dairy cattle. J. Anim Sci. 69, 1205-1213

West J.W., Haydon K.D., Mullinix B.G., Sandifer T.G., 1992. Dietary cation-anion balance and cation source effects on production and acid-base status of heat-stressed cows J. Dairy Sci. 75, 2776-2786

West J.W., Mullinix B.G., Sandifer T.G., 1991. Changing dietary electrolyte balance for dairy cows in cool and hot environments. J. Dairy Sci. 74, 1662-1674

\section{STRESZCZENIE}

\section{Zależność między bilansem kationowo-anionowym w dawkach dla krów mlecznych a niektórymi wskaźnikami we krwi oraz składem mleka}

Zmiany DCAD wywołały u krów mlecznych istotne zmiany w składzie mleka oraz w zawartości $\mathrm{Ca}, \mathrm{P}_{\text {nieogr. }}$ i $\mathrm{Mg} \mathrm{w}$ krwi, a także w niektórych wskaźnikach równowagi kwasowo-zasadowej. Gdy wartość DCAD przekroczyła +350 meq/kg s.m., w mleku obniżyła się zawartość suchej masy i białka. W przypadku laktozy taka zależność wystąpiła już przy DCAD $+330 \mathrm{meq} / \mathrm{kg}$ s.m. Największe stężenie Ca w osoczu krwi stwierdzono przy DCAD ok. +350 meq $/ \mathrm{kg}$ s.m. Wzrost DCAD obniżał stężenie Mg i $\mathrm{P}_{\text {nieorg. }}$ w surowicy krwi oraz $\mathrm{pCO}_{2}$ i BB krwi, a zwiększał zawartość tłuszczu w mleku i pH krwi. 